\section{OP-493 分子標的薬の転移部位別効果検討}

\section{福井大学医学部泌尿器科}

楠川 直也, 松田 陽介, 石田 泰一, 棚瀬 和弥, 伊藤 秀明，青木 芳隆，大山 伸幸，三輪 吉司， 秋野 裕信, 横山 修

目的：進行性腎癌および術後再発性腎癌に対して分子標的 薬を投与してその効果を部位別に検討した。対象：転移性 病変または局所再発病変を有する進行性腎癌で画像評価可 能であった 12 症例（ソラフェニブ投与群 7 例 スニチニ ブ投与群 5 例）結果：転移部位は肺 9 例、リンパ節 6 例、 副腎 4 例、膵臓 3 例、腎臓 2 例、肝臓 2 例、骨 2 例、局所 再発 2 例、脳 1 例であった。臓器別の縮小率は肺 $19.4 \%$ 、 リンパ節 $13.3 \%$ 、副腎 $14.5 \%$ 、膵臓 $35.2 \%$ 、腎臓 $8 \%$ 、肝臓 $56.9 \%$ 、骨 $53.8 \%$ 、局所再発部位は縮小を認めなかった。 ソラフェニブとスニチニブで縮小率を比較すると、ソラ

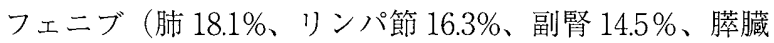
$44.4 \%$ 、腎臓 $8 \%$ 、肝臓 $22.7 \%$ 、骨 $53.8 \%$ ） スニチニブ（肺 $66.6 \%$ 、リンパ節 $12.4 \%$ 、膵臓 $25 \%$ 、肝臓 $67.6 \%$ ）転移部 位ではソラフェニブは 7 箇所でスニチニブは 4 箇所で縮小 を認めた。部位別では肺でスニチニブはソラフェニブに比 ベ有効率が高い傾向があった。ソラフェニブ投与群は PR3 例 SD2 例全体で $71 \%$ に効果を認めた。スニチニブ投与群 はPR3 例 SD1 例全体で $80 \%$ に効果を認めた。今後さら に症例を集積し、分子標的薬の有効性を検討する予定であ る。

\section{OP-494 分子標的療法が施行された腎癌症例にお けるリスク分類の検討}

\section{北海道大学大学院医学研究科腎泌尿器外科}

佐澤 陽, 篠原 信雄, 安部 崇重, 丸山 覚, 青柳 俊紀, 大澤 崇宏, 丸 晋太郎, 野々村 克也 【目的】近年、日本においても転移を有する腎癌に対し分 子標的薬が広く使用されるようになってきた。当科で治療 した症例にHengらが提唱しているリスク分類を適用し、 このリスク分類が予後予測に有用か検討した。【対象】対 象は婜癌有転移例としてソラフェニブまたはスニチニブが 投与された 18 例（免疫療法歴あり13 例）で、観察期間は 中央值 14.5 ケ月 $(0-42$ ケ月)である。予後不良因子として、 分子標的療法開始時の performance status (PS) 2 以上、 診断から 1 年以内の治療開始、へモグロビン低值、補正化 カルシウム高值、好中球高値、血小板高值の 6 因子を使 用した。Heng らに従い、予後不良因子 0 個を favorable risk、1-2 個を intermediate risk、3-6 個を poor risk と 分類し、これら 3 群で全生存期間を Kaplan-Meier 法で算 出した。【結果】全例での 50\%生存期間は23 ケ月。層別 解析では PS2 以上、補正化カルシウム高值、好中球高值、 血小板高值例で有意に生存期間が短かった。Favorable risk 1 例, intermediate risk 14 例, poor risk 3 例に分類さ れ、50\%生存期間はそれぞれ到達せず、32 ケ月、3 月月、 であり、各群の生存率に有意差 $(\mathrm{P}<0.01)$ を認めた。【結 論】多数例の検討が必要であるが、Heng らのリスク分類 は日本人の症例にも有用であると考えられた。
転移を有する腎細胞癌患者に対するエベロリムス（RAD001） のランダム化、二重盲検、プラセホ対照、多施設共同第 III 相詿験 (RECORD-1 試験) 一日本人サブグループでの検討

\begin{abstract}
静岡がんセンター泌尿器科 ${ }^{11}$, 北海道大学大学院医学研究科腎泌尿器外科学2), 札 帽医科大学泌尿器科 3 , 秋田大学医学部泌尿器科 $4^{4}$, 栃木県立がんセンター化学潦 法科 $^{5 \dagger}$, 千葉県立がんセンター泌尿器科 ( $^{6}$, 国立がんセンター中央病院泌尿器科 近畿大学医学部泌尿器科 ${ }^{8}$, 大阪府立成人病センター泌尿器科" , 倉敷中央病院泌 尿器科 ${ }^{10)}$, 德島大学大学院先端医療創生科学講座泌尿器科学分野 11 , 国立病院機構 四国がんセンター泌尿器科 ${ }^{22}$, 九州大学大学院医学研究院泌尿器科学分野 ルティスファーマ(株)オンコロジー臨床研究部 ${ }^{14)}$, 筑波大学大学院人間総合科学 研究科腎沙尿器科学・男性機能科学分野 15$\rangle$
\end{abstract}

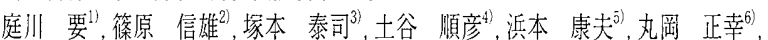

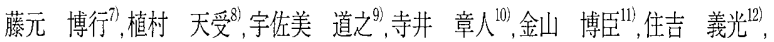
江藤 正俊 ${ }^{137}$, 春日 彰朗 ${ }^{14}$, 藤田 芳江 ${ }^{14}$, 赤座 英之成 ${ }^{13}$

偝景】 RADO01は、経口のmTOR阻害剂である。日本を含めた世界10力国で、VEGFR チロシンキナーゼ阻害剤 (VEGFr-TKI：ソラフェニブ又はスニチニブ) の治療で不 応となった転移を有する腎細胞癌 ( $\mathrm{mRCC}$ ) 患者を対象に、プラセボを対照とした RAD001 (1日1回10 mg) の)有效性及び安全性を检討方る目的てRECORD-1試験が实施 され、プラセボ群に比べPFSの)有意な延長が認められた。目的・方法】 RECORD-1試 験流、RAD001群（n=277）とプラセボ群 $(\mathrm{n}=139)$ に2：1で割り付けられた。今回、 RECORD-1試験に組み入れられた日本人24名（RAD001群15名、プラセボ群9名）での サブグループ解析を行うこととした。Cox比例ハザードモデルで推定した治療効果(PFS 中央值) のHR とその95\%信頼区間を算出し、PFS の群間比較に流Log-rank test妾用い た。また安全性について子検傠した。結果】 PFSO中央值法、RAD001群で5.75力月、 プラセボ群で3.61 カ月であった (HR: $0.26 ； 95 \%$ 信頼区間：0.08, $0.86 ： \mathrm{P}<0.025)$ 。本結 果は、RECORD-1試験全体の結果と同様つ伯向であった。また、安全性プロファイルに ついても全体の結果と同様の傾向であった。結語】RAD001は、他の分子標的薬治療 で不応となった日本人のmRCC患者に、有效性と安全性が認められた初の分子標的薬で あり、腎細胞癌の治療体系に大きな変化をもたらすものと期待される。

\section{OP-496転移性腎紐胞癌に対する低用量 IL-2 と IFN $a$ 併用療法の治療成績}

\section{筑波大学大学院人間総合科学研究科腎泌尿器外科 \\ 及川 剛宏, 小野澤 瑞樹, 宮崎 淳, 関戸 哲利, \\ 宮永 直人，河合 弘二，島居 徹，赤座 英之}

【目的】分子標的薬の導入により転移性腎癌に対する治療 が変化している中、本邦の第 2 相試験により低用量 IL-2 と IFN $a$ 併用療法の有効性が報告されている。当科に扔 ける本療法の成續を報告する。【方法】2001年から 2009 年までに本療法を施行した 19 例を対象とした。年齢の中 央值 61 歳、観察期間 45.7 力 (9.6-93.1) であった。IL-2(70 万単位 5 回/週）抢よびIFNa（600万単位 3 回/週）を 投与し 4 週毎に効果を判定した。治療対象の転移部位は、 肺のみ 8 例 $(42 \%)$ 、肺 +他部位 8 例、他部位のみ 3 例で あった。【成績】投与期間の中央值 8 週（4-16）であり、9 例は 12 週以上投与された。治療効果は PR3 例 $(16 \%) 、$ SD8 例 $(42 \%) 、 \mathrm{PD} 8$ 例であり、58\%が SD 以上と判定さ れた。PR 症例は肺転移のみ 1 例、肺 +他部位 2 例で、PR 例の転移藏器数は 2 個以下であった。6 例が癌死し、TTP は平均 27 週であった。PS、MSKCCリスク分類、組織型 が有意な予後因子であった。転移部位別の治療効果に有意 差は認められなかった。G3 以上の有害事象として、好中 球減少 $32 \%$ 、リンパ球減少 $26 \%$ 等が認められたが、これ らは過去の報告を大きく上回るものではなかった。【結論】 今回の成績は第 2 相試験の結果には及ばなかったが、肺転 移のみの症例が少なく、前治療を有する症例が多かったこ とが考えられる。症例を選択すれば本療法は有効な治療に なり得ると考えられた。 